\title{
Pregnancy Induced Autoimmune Warm Antibodies Hemolytic Anemia: A Case Report
}

\section{Schwangerschaftsinduzierte autoimmunhämolytische Anämie vom Wärmetyp: ein Fallbericht}

Authors

Affiliations
D. Laužikiené $\dot{e}^{1,2}$, D. Ramašauskaité ${ }^{1,2}$, T. Lūža ${ }^{2}$, R. Lenkutiené $\dot{e}^{3}$

${ }^{1}$ Obstetrics and Gynaecology Centre, Vilnius University Hospital SantariškiųKlinikos, Vilnius, Lithuania

2 Obstetrics and Gynaecology Clinic, Faculty of Medicine, Vilnius University, Vilnius, Lithuania

${ }^{3}$ Faculty of Medicine, Vilnius University, Vilnius, Lithuania

Key words
O pregnancy
O hemolytic anemia
O steroids
Schllüsselwörter
O Schwangerschaft
- hämolytische Anämie
- Steroide

received 21.4.2015

revised 21.8 .2015

accepted 25.8.2015

\section{Bibliography}

Dol http://dx.doi.org/

10.1055/s-0035-1558131

Geburtsh Frauenheilk 2015; 75:

1167-1171 @ Georg Thieme

Verlag KG Stuttgart · New York .

ISSN 0016-5751

Correspondence

Dalia Laužikiené

Obstetrics and Gynaecology

Centre

Vilnius University Hospital

SantariškiųKlinikos

Santariškiụ St. 2

LT-08406 Vilnius

Lithuania

laudaliadalia@gmail.com

\section{Abstract \\ $\nabla$}

Background: Autoimmune haemolytic anaemia (AIHA), caused primarily by pregnancy, is poorly described in the literature. There is especially little information on coping with cases that are not responsive to glucocorticoid treatment, monitoring a fetal condition, and identifying fetal haemolytic anaemia as early as possible.

Case: A case of pregnancy-induced autoimmune haemolytic anaemia is reported with major problems in differential diagnosis, treatment and the risks posed to both the mother and the fetus. The anaemia went into spontaneous remission of the disease several weeks after delivery.

Conclusion: Autoimmune haemolytic anaemia is rarely reported in literature, but can be dangerous for both fetus and mother. It therefore should be described and discussed among obstetricians and gynaecologists, and the etiopathogenesis should be further studied.

\section{Zusammenfassung \\ V}

Hintergrund: Es gibt nur wenige Berichte zur schwangerschaftsinduzierten autoimmunhämolytischen Anämie (AIHA). Noch weniger Informationen gibt es über die adäquate Vorgehensweise bei Patientinnen, die nicht auf eine Behandlung mit Glukokortikoiden ansprechen, sowie zur Bedeutung einer Überwachung des fetalen Zustands und einer frühestmöglichen Ermittlung einer fetalen hämolytischen Anämie.

Fallbericht: Es wird hier der Fall einer Frau mit schwangerschaftsinduzierter autoimmunhämolytischer Anämie berichtet, bei der erhebliche Probleme bei der Stellung der Differenzialdiagnose auftraten. Es wird über die Behandlung und Risiken für Mutter und Kind berichtet. Einige Wochen nach der Entbindung trat eine Spontanremission der Anämie ein.

Schlussfolgerung: In der Literatur gibt es nur wenige Berichte zur autoimmunhämolytischen Anämie, die aber ein erhebliches Risiko für Mutter und Fetus darstellt. Sie sollte daher eingehend beschrieben und unter Gynäkologen sowie Geburtshelfern diskutiert werden. Es sind weitere Studien zur Klärungen der Ätiopathogenese gefordert.

\begin{tabular}{|c|c|c|c|}
\hline \multicolumn{2}{|c|}{$\begin{array}{l}\text { Abbreviations } \\
\nabla\end{array}$} & IgG, IgM & \multirow{2}{*}{$\begin{array}{l}\text { immunoglobulin G, } \\
\text { immunoglobulin M } \\
\text { lactate dehydrogenase }\end{array}$} \\
\hline AFLP & acute fatty liver of pregnancy & LDH & \\
\hline AIHA & autoimmune haemolytic anaemia & MAHA & microangiopathic haemolytic \\
\hline ALT & alanine aminotransferase & & anaemia \\
\hline APS & antiphospholipid syndrome & MCA & middle cerebral artery \\
\hline APTT & activated partial thromboplastin time & $\mathrm{MCH}$ & mean cell haemoglobin \\
\hline AST & aspartate aminotransferase & $\mathrm{MCHC}$ & mean corpuscular haemoglobin \\
\hline DAT & direct antiglobulin test & & concentration \\
\hline $\mathrm{EB}$ & Epstein-Barr virus & MCV & mean cell volume \\
\hline $\mathrm{Hb}$ & haemoglobin & NST & nonstress test \\
\hline HUS & haemolytic uremic syndrome & PSV & peak systolic velocity \\
\hline & & RHD & $\operatorname{Rh}(\mathrm{D})$ factor \\
\hline
\end{tabular}


Stago protrombin assay thrombotic thrombocytopenic purpura

\section{Introduction}

Autoimmune haemolytic anaemia (AIHA), caused primarily by pregnancy, is poorly described in the literature [1-4]. AIHA is characterized by the development of antibodies directed against one's own red cell antigens. When such an autoantibody belongs to the $\operatorname{IgG}$ class, the condition is potentially dangerous to both the mother and the fetus, since IgG crosses the placenta readily [4].

In most reported cases, idiopathic AIHA occurred late in the pregnancy and responded well to steroid therapy and/or transfusions, with slight or no haemolytic process in the newborn. We therefore encountered a lack of information about how to cope with a case of AIHA that does not respond to glucocorticoid treatment and how to monitor a fetal condition and suspect possible fetal haemolytic anaemia as early as possible. And which is better: to treat the mother and fetus in utero until the term or to treat them separately post partum? These questions merit the depiction of this rare case for reporting and further discussions.

A case of pregnancy-induced autoimmune haemolytic anaemia is reported herein along with the major problems in differential diagnosis, treatment and the risks posed to both the mother and the fetus.

\section{Case Report}

$\nabla$

A 34-year-old pregnant patient in the 29th week of gestation presented to the emergency room with severe weakness and headache. She had a history of six medical abortions and one normal pregnancy and delivery at term. Until three days previously, she had felt fine throughout this pregnancy and had not had any complaints. At age 12 she had had a thrombotic thrombocytopenic purpura episode that was treated by steroids for 3 years. Since then, she did not have any symptoms of that or any other severe disease.

Physical examination revealed marked pallor and icteric discoloration of her skin and conjunctiva, tachycardia and tachypnea. The fetal status was normal. The nonstress tests (NST) were reactive. Ultrasound did not show any fetal abnormalities, the amount of amniotic fluid was normal, and dopplerometry of umbilical, uterine and middle cerebral arteries were within normal range.

An automated cell counter of peripheral blood showed a normal total leukocyte count with normal differentiation and a normal platelet count. Evaluation of blood parameters revealed features of severe anaemia (haemoglobin [Hb] - $38 \mathrm{~g} / \mathrm{l}$ ) with normocytosis (MCV - 86.4 fl) and normal MCH (30.4 pg) and MCHC (352 g/l) as well as reticulocytopenia $0.38 \%$. The haematocrit level was decreased to $0.108 \mathrm{l} / \mathrm{l}$. Biochemical analysis showed indirect hyperbilirubinaemia (28.4 mkmol/l) with normal AST (36 U/L) and ALT $(29 \mathrm{U} / \mathrm{L})$ and increased LDH $(552 \mathrm{U} / \mathrm{L})$. Increased fibrinogen $(4.38 \mathrm{~g} / \mathrm{L})$ and D-dimer test $(1835 \mathrm{mkg} / \mathrm{L})$ and normal APTT (29.4 s) and SPA (112\%) and SPA (0.95 INR) were found. Urine analysis was normal. Serum iron $(70.4 \mathrm{mkmol} / \mathrm{l})$, ferritin $(418.9 \mathrm{mkg} / \mathrm{l})$ and haptoglobin $(<0.08 \mathrm{~g} / \mathrm{L})$ were detected in normal ranges. Erythropoietin concentration was 104 U/l. Molecular tests for acute Parvo B19 virus were negative. EB virus IgM was negative and IgG positive. An abdominal ultrasound showed slight hepatosplenomegaly. Bone marrow aspiration showed expanded erythropoiesis and there were no abnormal cells. The patient's blood group was A (II), RHD positive. Direct (IgG) and indirect Coomb's tests were positive. Rhesus phenotype ccEe. The anti-RHD antibodies titre was $1: 2000$.

Six units of group A (II), RHD-negative packed red cells were transfused and treatment with corticosteroids was initiated (two days of dexamethasone $6 \mathrm{mg}$ intramuscularly at 12-hour intervals. Oral prednisolone was started at $1 \mathrm{mg} / \mathrm{kg}$, for a total $60 \mathrm{mg}$ po bid from the third day) with co-administration of fraxiparine, proton pump inhibitors and folic acid.

The fetal status was observed daily and maternal blood tests were checked regularly. Despite corticosteroid treatment, haemolysis was present and ongoing with persistent reticulocytopenia. Fetal anaemia was detected with non-invasive fetal middle cerebral artery dopplerometry at day 9 of treatment (a. cerebri media PS velocity increased up to 0.67 ). Due to an inadequate response to medical conservative treatment and worsening fetal wellbeing, it was decided to terminate the pregnancy. A Caesarean section was performed at gestation of 30 weeks and four days. The patient was asked whether she wanted to undergo a splenectomy during the surgery, but she refused this option. During the operation, 5 units of group A (II), RHD-negative packed red cells were transfused.

A female newborn was delivered with severe indirect hyperbilirubinemia (150 mkmol/l) and mild anaemia (haemoglobin $136 \mathrm{~g} / \mathrm{l})$. Blood group A (II), RHD positive and positive indirect Coombs test led to diagnosis of severe rhesus alloimmunization of a newborn. The treatment of the newborn was initiated with an exchange transfusion of blood, followed by fototeraphy. On the second day the infant experienced mild seizures, which were treated by liuminal. After her status was stabilized, at 6 days old the newborn was transferred to a paediatric hospital's newborn intensive care unit for further treatment and investigation. The infant was followed up by neonatologists. Despite prematurity, alloimmune haemolytic anaemia with reticulocytopenia was observed. Severe haemolytic anaemia was initially corrected after delivery with an exchange hemotransfusion followed by two hemotransfusions during the first month. On follow-up three months later, normal haemoglobin and reticulocytes counts were observed.

The mother was followed up after the delivery and medical treatment was continued. After several weeks, her blood haemoglobin levels reached $124 \mathrm{~g} / \mathrm{l}$ and reticulocitosis of $3.68 \%$ was present ( Table 1). Prednisolone dosage was decreased to $0.5 \mathrm{mg} / \mathrm{kg}$ per day.

\section{Comment}

$\nabla$

We have presented a case of autoimmune haemolytic anaemia that was detected accidently and presented as severe anaemia, with a wide range of differential diagnosis. Clinical presentation and laboratory parameters were consistent with haemolysis and a working diagnosis of warm antibodies autoimmune haemolytic anaemia (AIHA) was made.

Haemolysis occurs in other pregnancy conditions. HELLP syndrome occurs in approximately one out of 500 pregnancies, AFLP in one out of 10000 pregnancies, and TTP/HUS in one out of 
Table 1 Laboratory test results of mother's blood.

\begin{tabular}{|c|c|c|c|c|c|c|}
\hline & $\begin{array}{l}\text { On admission } \\
\text { 2013-09-09 }\end{array}$ & $\begin{array}{l}\text { After } \\
\text { transfusion } \\
\text { 2013-09-11 }\end{array}$ & $\begin{array}{l}\text { Before } \\
\text { C-section } \\
\text { 2013-09-17 }\end{array}$ & $\begin{array}{l}\text { One week } \\
\text { post partum } \\
2013-09-23\end{array}$ & $\begin{array}{l}\text { Two weeks } \\
\text { post partum } \\
2013-09-30\end{array}$ & $\begin{array}{l}\text { One month } \\
\text { post partum } \\
2013-10-07\end{array}$ \\
\hline $\mathrm{Hgb}(\mathrm{g} / \mathrm{l})$ & 38 & 82 & 65 & 93 & 95 & 124 \\
\hline Reticulocytes (\%) & 0.38 & 0,5 & 0.33 & 0.42 & 5.7 & 3.68 \\
\hline Total bilirubin (mkmol/l) & 47 & 28 & 30.4 & 19.5 & 17.6 & 13.0 \\
\hline
\end{tabular}

Table 2 Differential diagnosis of haemolysis in pregnancy.

\begin{tabular}{|c|c|c|c|c|}
\hline & HELLP & AFLP & TTP & HUS \\
\hline Haemolysis & + to +++ & 0 to + & +++ & ++ to +++ \\
\hline Elevated LDH & ++ to +++ & + to ++ & +++ & ++ to +++ \\
\hline Elevated liver enzymes & ++ to +++ & ++ to +++ & 0 to + & 0 to + \\
\hline Low platelet count & ++ to +++ & + to ++ & +++ & ++ to +++ \\
\hline Total bilirubin & + & ++ to +++ & + to ++ & + to ++ \\
\hline Proteinuria & +++ & + & + to ++ & + to +++ \\
\hline Renal failure & 0 to ++ & + & 0 to ++ & ++ to +++ \\
\hline CNS disease & \pm & + & +++ & \pm \\
\hline DIC & 0 to ++ & 0 to +++ & 0 & 0 \\
\hline Hypoglycaemia & 0 to + & + to +++ & 0 & 0 \\
\hline Fever & 0 & + & ++ & 0 \\
\hline Peak time & 3rd trimester & 3rd trimester & 2nd trimester & Postpartum \\
\hline
\end{tabular}

\pm : variably present; +: mild; ++: moderate; +++: severe

a Modified from [5], and Keith R. Hematology-Oncology 2003; 17: 10

100000 pregnancies. These and other disease differentiations are listed in Table 2 [5].

AIHA is an uncommon condition, and the cause of aberrant antibody production is unknown. Typically, both the direct and indirect antiglobulin (Coombs) tests are positive. The direct antiglobulin test (DAT) demonstrates the presence of antibodies on the surface of red blood cells and is the hallmark of autoimmune haemolysis [6]. Anaemias caused by these factors are mainly due to warm-active autoantibodies ( 80 to $90 \%$ ) and may be classified as primary (idiopathic) or secondary due to underlying diseases or other factors [7]. Warm haemolysis refers to IgG autoantibodies, which maximally bind red blood cells at body temperature $\left(37^{\circ} \mathrm{C}\right)[6]$.

The literature describes clinically severe haemolytic anaemias with negative direct and indirect Coombs tests. This pathology usually is called pregnancy-induced haemolytic anaemia [7-14]. Katsuragi et al. [9] report a case of haemolytic anaemia with negative Coombs test in which an increased immunoglobulin G (IgG) level on maternal red blood cells was observed throughout pregnancy by the flow cytometry method.

It is likely that in previous reports of haemolytic anaemias during pregnancy with a negative DAT where a favourable response to corticosteroids was seen, the number of antibody molecules on the erythrocytes was too small to produce a positive test result $[3,15]$.

There are just a few cases with positive DAT reported in English literature. Baumann and Rubin [1] presented a case of a patient who had experienced symptoms of severe Coombs positive warm antibodies AIHA during the final weeks of pregnancy with haemolytic disease found in the newborn. The disease responded to steroid treatment and blood transfusions with spontaneous recovery post partum. The authors reviewed literature dated from 1955 to 1970 that was consistent with this case.
Bendraad et al. [3] described the case of a young patient who suffered from severe idiopathic AIHA, with onset during two consecutive pregnancies, who had a good response to glucocorticoids and hemotransfusions. She experienced total remission of the disease post partum with uneventful outcomes for mother and child.

Tsai [2] and Soo-Chin [4] with co-authors presented two different cases of idiopathic warm antibody (IgG) autoimmune haemolytic anaemias occurring in the late third trimester of pregnancy with haemolytic processes. Both patients responded to steroid therapy and no transfusion was needed. Healthy babies were delivered naturally with no evidence of haemolysis.

Despite reported cases, there is no case report in which autoimmune haemolytic anaemia appeared quite early (around the 30th week) in pregnancy and was resistant to steroidal treatment with marked reticulocytopenia.

No cause of reticulocytopenia was identified in any case in the existing literature. Bone marrow aspiration showed expanded erythropoiesis and there were no abnormal cells. Molecular tests for acute Parvo B19 virus were negative. EB virus IgM was negative. Although most cases of autoimmune haemolysis are idiopathic, potential causes such as lymphoproliferative disorders, drugs, infections or autoimmune diseases should always be sought.

No etiological factor was found in the literature that could be associated with the disease, but the history of thrombotic thrombocytopenic purpura episode at age 12 in this case should be kept in mind as there could be unexplained immunological mechanisms connecting these two problems.

Corticosteroids is the usual first-line treatment for patients with warm antibody AIHA. Immunosuppression may be attempted after other measures have failed. However, this treatment should be considered teratogenic and contraindicated during pregnancy unless absolutely required to treat maternal life-threatening con- 
ditions. At present, the greatest known risk to infants exposed to cytostatics in utero is growth restriction or prematurity, yet this risk is unlikely to be related to cytostatics exposure alone. It appears that azathioprine at the lowest effective dose is relatively safe in pregnancy, when the benefits of this medication outweigh the possible risks to the fetus/newborn. Cyclophosphamide exposure in the second and third trimesters does not appear to be associated with birth defects or neurologic abnormalities, but such infants are at risk of low birth weight and for bone-marrow suppression at birth. Mycophenolate mofetil can be a cause of ear malformations. Long-term effects in humans from exposure to cytostatics during pregnancy are unknown $[16,17]$.

Monoclonal antibodies anti-CD20 (rituximab) has produced prolonged remissions in a proportion of cases and anti-CD52 (Campath-lH) has been tried successfully in a few cases. Klink and Elburg with co-authors demonstrated that rituximab passes the placenta and inhibits neonatal B-lymphocyte development. However, after 6 months, B-lymphocyte levels normalized and vaccination titres after 10 months were adequate. No infectionrelated complications occurred. Rituximab administration during pregnancy appears to be safe for the child [18]. Another study presented rituximab therapy as a viable option for deferring cytotoxic therapy early during pregnancy; it might help reduce the risk of fetal malformation or abortion [19]. Rituximab is reported to be effective in about $80-90 \%$ of cases of warm AIHA [20].

In a recent guideline, high-dose immunoglobulin was not recommended for use in AIHA, except under certain life-threatening circumstances [21]. High-dose immunoglobulin has been used but with less success than in idiopathic thrombocytopenic purpura [17].

The first problem encountered in management of the present case was when the patient refused steroidal treatment because she feared the treatment could be dangerous for her baby. After long negotiations she accepted the treatment. Although management with corticosteroids was started, it was found insufficient, because of persistent haemolysis. Nevertheless, while the literature describes the therapeutic utility of corticosteroids, it is not confirmed to be universally successful. The effect in some cases was achieved only with top-up blood transfusions [8]. Other medical options for treating AIHA are not well described in the literature for use during pregnancy or are too inconsistent to be applied in a gravid state.

Blood transfusion therapy in AIHA is challenging, and the most compatible red blood cells (i.e., those with the least cross-reacting antibodies) should be given [6]. The grouping and crossmatching packed red cells for transfusion was complicated due to excessive agglutination of erythrocytes. The patient's blood group was A (II), RHD-positive and group A (II), RHD-negative packed red cells were transfused.

Despite the problems in management of the disease, the main challenge in the present case was establishing criteria for fetal condition and prognosis. Since the main pathogenetic factor in this case was IgG auto-antibodies against RHD factor, it was suspected that these antibodies could cross the placental barrier and, if the fetal blood group proved RHD positive, they could induce a condition equivalent to rhesus alloimmunization for the fetus.

In some reported cases with AIHA during pregnancy [1,15,22, 23], a wide range of haemolytic diseases in newborns was observed with the need of exchange hemotransfusion occasionally. In the literature no recommendations were found about how to monitor fetal conditions in AIHA, so standard investigations for assessment of the severity of fetal anaemia in RHD alloimmunization were used. Pretlove et al. [24] in their systematic review provided compelling evidence that a Doppler assessment of the fetal middle cerebral artery (MCA) peak systolic velocity (PSV) is the best non-invasive tool for predicting fetal anaemia in at-risk pregnancies. Invasive techniques such as amniocentesis or cordocentesis are more hazardous to the mother and fetus and should be reserved for patients with increased MCA-PSV [25].

Fetal status was observed with an NST several times a day and Dopplerometry of fetal middle cerebral artery peak systolic velocity was taken once a day. MCA-PSV was in normal range until the ninth day of the treatment and at the same moment it was clear that medical treatment of AIHA fails. Because of inadequate response to conservative medical treatment and signs of severe fetal anaemia, it was decided to terminate the pregnancy. Due to the urgent need to help the mother and fetus, a C-section was done.

The post partum newborn demonstrated severe haemolytic anaemia and underwent an exchange transfusion which is preferred over a simple transfusion because it not only corrects anaemia but also reduces haemolysis by replacing antibodycoated neonatal RBCs with donor RBCs. Donor RBCs do not have the sensitizing antigen, and remove a portion of the unbound maternal antibody [26].

The maternal patient was followed up by haematologists post partum and, surprisingly, haemolysis stopped. Such a scenario is consistent with available data in literature. The disease could be referred to as pregnancy-induced autoimmune warm antibodies haemolytic anaemia.

Unfortunately, this condition has rarely been reported in literature, and not enough data are available for management of such cases, especially when steroidal treatment fails and there are challenges in determining criteria for fetal prognosis. Pathogenesis must be further studied, keeping in mind the fetoplacental immunological, hormonal and biochemical factors that could be responsible for this condition occurring during pregnancy and disappearing post partum.

Teaching points:

1. AIHA should be considered in cases of severe anaemia during pregnancy.

2. The main purpose of the treatment of AIHA is to stop haemolysis and correct anaemia.

3. The nature of the AIHA is still not completely understood and needs further investigation.

\section{Conflict of Interest}

$\nabla$

None.

\section{References}

1 Baumann R, Rubin $H$. Autoimmune hemolytic anemiaduring pregnancy with hemolytic disease in the newborn. Blood 1973; 41: 293297

2 Tsai YC, Chang JM, Chang JC et al. Idiopathic autoimmune hemolytic anemia during pregnancy. J Formos Med Assoc 1994; 93: 328-331

3 Benraad CE, Scheerder HA, Overbeeke MA. Autoimmune haemolytic anaemia during pregnancy. Eur J Obstet Gynecol Reprod Biol 1994; 55: 209-211

$4 \mathrm{Ng}$ SC, Wong KK, Raman S et al. Autoimmune haemolytic anaemia in pregnancy: a case report. Eur J Obstet Gynecol Reprod Biol 1990; 37 : $83-85$ 
5 Pourrat 0 , Coudroy R, Pierre F. Differentiation between severe HELLP syndrome and thrombotic microangiopathy, thrombotic thrombocytopenic purpura and other imitators. Eur J Obstet Gynecol Reprod Biol 2015; 189: 68-72

6 Gurpreet D, Cornett PA, Tierney L. Hemolytic anemia. Am Fam Physician 2004; 69: 2599-2607

7 Cunningham FG et al. Hematological Disorders. In: Cunningham FG et al., eds. Williams Obstetrics. 23rd ed. New York: McGraw-Hill; 2010: 1079-1083

8 Kumar R, Advani AR, Sharan J et al. Pregnancy induced hemolytic anemia: an unexplained entity. Ann Hematol 2001; 80: 623-626

9 Katsuragi S, Sameshima H, Omine M et al. Pregnancy-induced hemolytic anemia with a possible immune-related mechanism. Obstet Gynecol 2008; 111: 528-529

10 Sharma P, Sthapit $R$. Unexplained hemolytic anemia of pregnancy: case report with review of related literature. Nepal Journal of Obstetrics and Gynaecology 2008; 3: 49-50

11 Craig GA, Turner RL. A case of symptomatic haemolytic anaemia in pregnancy. Br Med J 1955; 4920: 1003-1005

12 Dominico SA, Janmohamed M, Magesa A et al. Coombs negative hemolytic anemia of unknown origin in pregnancy. J Blood Lymph 2012; 2: 103

13 Sokol RJ, Hewitt S, Stamps BK. Erythrocyte autoantibodies, autoimmune haemolysis and pregnancy. Vox Sang 1982; 43: 169-176

14 Starksen NF, Bell WR, Kickler TS. Unexplained hemolytic anemia associated with pregnancy. Am J Obstet Gynecol 1983; 146: 617-622

15 Lawe JE. Successful exchange transfusion of an infant for AIHA developing late in mother's pregnancy. Transfusion 1982; 22: 66-68
16 Ensworth $S$. Anti-rheumatic medications during pregnancy and lactation. J Rheumatol 2002; 2: 1-16

17 Hoffbrand AV, Moss PAH, Pettit JE. Essential Haematology. 5th ed. New York: Wiley-Blackwell; 2006: 58-72

18 Klink DT, van Elburg RM, Schreurs MW et al. Rituximab administration in third trimester of pregnancy suppresses neonatal B-cell development. Clin Dev Immunol 2008; 2008: 271363

19 Friedrichs B, Tiemann M, Salwender $H$ et al. The effects of rituximab treatment during pregnancy on a neonate. Haematologica 2006; 91: 1426-1427

20 Barcellini $W$. Haemostasis and immunity: cross-talking systems? Blood Transfuse 2014; 12: 348-349

21 Zanella A, Barcellini W. Treatment of autoimmune hemolytic anemias. Haematologica 2014; 99: 1547-1554

22 Chaplin HJ, Cohen R, Bloomberg G et al. Pregnancy and idiopathic autoimmune haemolytic anaemia: a prospective study during 6 months gestation and 3 months post-partum. Br J Haematol 1973; 24: 219229

23 Issaragrisil S, Kruatrachue M. An association of pregnancy and autoimmune haemolytic anaemia. Scand J Haematol 1983; 31: 63-68

24 Pretlove SJ, Fox CE, Khan KS et al. Noninvasive methods of detecting fetal anaemia: a systematic review and meta-analysis. BJOG 2009; 116 : 1558-1567

25 Rosse W, Schrier SL. Clinical features and diagnosis of autoimmune hemolytic anemia: Warm agglutinins. UpToDate 2013

26 Darlene A, Calhoun DO. Postnatal diagnosis and management of alloimmune hemolytic disease in newborn. UpToDate 2015 